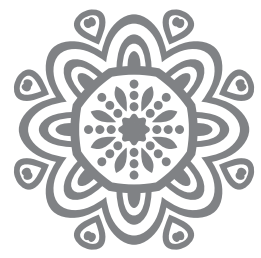

\title{
Pendidikan Multikultural dalam Perspektif al-Qur'an
}

\author{
Heru Suparman \\ Dosen Fakultas Tarbiyah dan Alumni Doktor Pendidikan Berbasis Al-Qur'an, Program Pascasarjana \\ Institut PTIQ Jakarta,E-mail:Pahe165@yahoo.co.id \\ Hp: 08128205415.
}

\begin{abstract}
Abstrak: Penemuan riset menyatakan bahwa tinjauan atau maksud dari al- Qur'an tentang pendidikan multikultural tidak bertentangan dengan pengajaran Islam dalam hal apapun, khususnya Al-Qur'an sebagai sumber dari hukum Islam. Perbedaan yang ada pada kenyataannya menjadi aset para cendekiawan untuk dikaji, sebagaimana Al-Qur'an telah menjelaskannya. Melalui pendidikan multikultural, diharapkan pada setiap orang atau golongan untuk menerima dan mengapresiasi perbedaan diantara mereka, hidup dengan kata-kata yang harmonis agar terbentuk kedamaian dan bangsa yang makmur.

Penemuan menarik lainnya pada riset ini yaitu ada lima peran pendidikan multikultural dalam pandangan Al-Quran; belajar untuk hidup pada perbedaan, membangun tiga aspek saling (mempercayai dan memahami satu sama lain, berpikiran terbuka, apresiasi dan interdependensi), sebagaimana tidak ada resolusi konflik kekerasan dan perdamaian. Faktanya, beberapa karakteristik dibentuk dengan ayat- ayat Al-Qur'an dan tafsir sebagai referensi yang menunjukan konsep pendidikan multikultural sejajar dengan pegajaran Islam mengatur struktur umat manusia yang hidup di bumi khususnya dalam konteks pendidikan.
\end{abstract}

Kata Kunci: Pendidikan, multikultural, al-Qur'an

\section{A. Sekilas Soal Multikultural}

Merupakan kenyataan yang tidak bisa ditolak bahwa Indonesia terdiri dari berbagai kelompok etnis, budaya, agama dan lain-lain sehingga Indonesia secara sederhana dapat disebut sebagai masyarakat multikultural. Tetapi 
pada pihak lain, realitas multicultural tersebut berhadapan dengan kebutuhan mendesak untuk mendekonstruksi kembali kebudayaan nasional Indonesia yang dapat menjadi integrating force yang mengikat seluruh keragaman etnis dan budaya tersebut.

Wacana multikulturalisme dalam konteks Al-Qur'an adalah mengupayakan pengenalan dan pemahaman suku, agama, ras dan antargolongan dalam upaya memahami heterogenitas, yakni menerapkan hakekat pendidikan multikultural itu sendiri. ${ }^{1}$ Pendidikan multikultural juga didasarkan pada keadilan sosial dan persamaan hak dalam pendidikan. Dalam doktrin Islam, ajaran kita tidak boleh membeda-bedakan etnis, ras, dan lain sebagainya. Manusia sama, yang membedakan adalah ketaqwaan kepada Allah SWT. Hal ini ditegaskan dalam Surat Al-Hujurat/49:13. Dalam kaitanya dengan pendidikan multikultural hal ini mencerminkan bagaimana tingginya penghargaan Islam terhadap ilmu pengetahuan. Dalam Islam tidak ada pembedaan dan pembatasan di antara manusia dalam haknya untuk menuntut atau memperoleh ilmu pengetahuan.

Kajian ini meninjau pendidikan multikultural tidak terlepas dari keseluruhan dinamika budaya suatu masyarakat. Oleh sebab itu, tinjauan studi kultural harus dilakukan melalui lintas batas (border crossing) yang melangkahi batas-batas pemisah yang tradisional dari disiplin-disiplin dunia akademik yang kaku sehingga pendidikan multikultural tidak terkait pada horizon yang sempit yang hanya melihat pendidikan di sekolah (school education) dan proses pendidikan tidak melebihi sebagian proses transmisi atau reproduksi ilmu pengetahuan kepada generasi yang akan datang. ${ }^{2}$ Harapan yang tersimpan yaitu terciptanya kedamaian yang sejati, keamanan yang tidak disertai dengan kecemasan, kesejahteraan yang tidak dihantui manipulasi dan kebahagiaan yang terlepas dari jaring-jaring manipulasi rekayasa sosial. Dari deskripsi di atas dapat diambil kesimpulan dasar-dasar pelaksanaan pendidikan multikulturalisme sebagai berikut:

1. Pendidikan multikulturalisme merupakan sebuah proses pengembangan (developing). Yaitu sebagai suatu proses yang tidak dibatasi oleh ruang, waktu, subjek, objek, dan relasinya. Proses ini biasa dilakukan dimana saja, kapan saja, oleh siapa saja, untuk siapa saja, dan berkaiatan dengan siapa saja.

${ }^{1}$ Zubaedi, Telaah konsep Multikulturalisme Dan Implementasinya dalam Dunia Pendidikan, Yogyakarta: Hermenia, Program Pasca Sarjana, 2004, hal. 2.

${ }^{2}$ Imam Machali, Musthofa, Pendidikan Islam dan Tantangan Globalisasi (Buah Pikiran Seputar; Filsafat, Politik, Ekonomi, Sosial dan Budaya), ... hal. 266. 
2. Pendidikan multikulturalisme mengembangkan seluruh potensi manusia, yaitu potensi intelektual, potensi sosialreligius, moral, ekonomi, teknis, kesopanan, dan tentunya potensi budaya.

3. Pendidikan multikulturalisme adalah pendidikan yang menghargai heterogenitas dan pluralitas. Pendidikan yang menjunjung tinggi keragaman budaya, etnis, dan aliran agama, yaitu sikap yang sangat urgen untuk disosialisasikan. ${ }^{3}$

\section{B. Konsep Qur'ani Pendidikan Multikulturalisme}

Konsep Qur'ani pendidikan multikultural meliputi lima karakter, yaitu belajar hidup dalam perbedaan, membangun tiga aspek mutual (saling percaya, pengertian, dan menghargai), terbuka dalam berfikir, apresiasi dan interdependensi, serta resolusi konflik dan rekonsiliasi nirkekerasan. Dari beberapa karakteristik tersebut, diformulasikan dengan ayat-ayat al-Quran dan tafsir sebagai dalil, bahwa konsep pendidikan multikultural ternyata selaras dengan ajaran-ajaran Islam dalam mengatur tatanan hidup manusia di muka bumi ini, terutama sekali dalam konteks pendidikan. ${ }^{4}$

Karekteristik pendidikan multikultural meliputi lima komponen, yang tersebut di atas, yaitu:

\section{Belajar Hidup dalam Perbedaan}

Pendidikan selama ini lebih diorientasikan pada tiga pilar pendidikan, yaitu menambah pengetahuan, pembekalan keterampilan hidup (life skill), dan menekankan cara menjadi "orang" sesuai dengan kerangka berfikir peserta didik. Realitasnya dalam kehidupan yang terus berkembang, ketiga pilar tersebut kurang berhasil menjawab kondisi masyarakat yang semakin mengglobal. Oleh karena itu diperlukan satu pilar strategis yaitu belajar saling menghargai akan perbedaan, sehingga akan terbangun relasi antara personal dan intrapersonal. Dalam terminologi Islam, realitas akan perbedaan tak dapat dipungkiri lagi, sesuai dengan firman Allah dalam surat al-Hujurat/47: 13 yang menekankan bahwa Allah SWT. menciptakan manusia yang terdiri dari berbagai jenis kelamin, suku, bangsa yang berbeda-beda. Perbedaan-perbedaan yang ada di sekitar kehidupan manusia telah tertulis dalam Al-Qur'anul Karim sebagaimana Allah SWT. telah berfirman dalam surat al-Hujurat [49] 13 sebagai berikut:

${ }^{3}$ Imam Machali dan Musthofa, Pendidikan Islam dan Tantangan Globalisasi (Buah Pikiran Seputar; Filsafat, Politik, Ekonomi, Sosial dan Budaya), ... hal. 267.

${ }^{4}$ Zakiyuddin Baidhawy, Pendidikan Agama Berwawasan Multikultural, Jakarta: Erlangga, 2005, hal. 74-84 


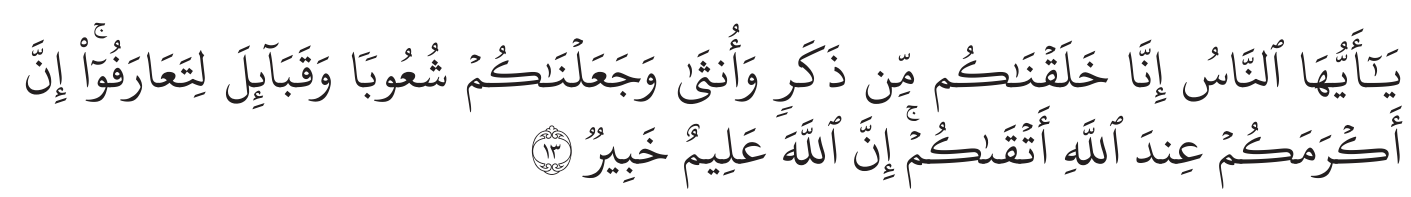

Hai manusia, sesungguhnya Kami menciptakan kamu dari seorang laki-laki dan seorang perempuan dan menjadikan kamu berbangsa-bangsa dan bersuku-suku supaya kamu saling kenal-mengenal. Sesungguhnya orang yang paling mulia diantara kamu disisi Allah ialah orang yang paling takwa diantara kamu. Sesungguhnya Allah Maha Mengetahui lagi Maha Mengenal (QS al-Hujurat [49] 13).

M. Quraish Shihab ketika menafsirkan ayat ini menjelaskan bahwa:

Hai manusia, sesungguhnya Kami menciptakan kamu dari seorang laki-laki dan seorang perempuan, yakni Adam dan Hawa, atau dari sperma (benih laki-laki) dan ovum (indung telur perempuan), serta menjadikan kamu berbangsa-bangsa juga bersuku-suku supaya kamu saling kenal mengenal yang mengantar kamu untuk bantu- membantu serta saling melengkapi, sesungguhnya yang paling mulia di antara kamu di sisi Allah ialah yang paling bertakwa di antara kamu. Sesungguhnya Allah Maha Mengetahui lagi Maha Mengenal sehingga tidak ada sesuatu pun yang tersembunyi bagi-Nya, walau detak detik jantung dan niat seseorang. Penggalan pertama ayat di atas sesungguhnya Kami menciptakan kamu dari seorang laki-laki dan seorang perempuan adalah pengantar untuk menegaskan bahwa semua manusia derajat kemanusiaanya sama di sisi Allah, tidak ada perbedaan antara satu suku dan yang lain. Tidak ada juga perbedaan pada nilai kemanusiaan antara laki-laki dan perempuan karena semua diciptakan dari seorang laki-laki dan seorang perempuan. Pengantar tersebut mengantar pada kesimpulan yang disebut oleh penggalan terakhir ayat ini yakni "Sesungguhnya yang paling mulia di antara kamu di sisi Allah ialah yang paling bertakwa". Karena itu, berusahalah untuk meningkatkan ketakwaan agar menjadi yang termulia di sisi Allah". ${ }^{5}$

Allah SWT. menciptakan manusia dengan bermacam-macam perbedaan supaya bisa saling berinteraksi mengenal antara satu dengan yang lainnya. Perbedaan bangsa dan suku tentu akan melahirkan bermacam budaya yang ada di masyarakat. Berangkat dari perbedaan tersebut maka setiap budaya akan mempunyai norma atau standar-standar tingkah laku yang terdapat di dalam masyarakat bermacam-macam. ${ }^{6}$ Sedikit banyak norma-norma itu berlainan antara satu individu atau kelompok dengan individu atau kelompok yang lain, karena

${ }^{5}$ M. Quraish Shihab, Tafsir Al-Misbah Pesan, Kesan dan Keserasian Al-Qur'an Vol. 12, Jakarta: Lentara Hati, 2002 hal. 615-616.

${ }^{6}$ Sanapiah Faisal, Sosiologi Pendidikan, Surabaya: Usaha Nasional, hal. 379. 
sistem nilai dan keyakinan yang berkembang di dalam masyarakat-masyarakat tertentu, ditinjau dari sudut kebudayaan, memisahkan masyarakat-masyarakat itu dari masyarakat-masyarakat yang lain sehingga berkembang corak nilai-nilai dan keyakinan yang berbeda-beda. ${ }^{7}$ Ini menjadi sebuah kenyataan yang melatarbelakangi timbulnya bermacam-macam perbedaan dan keragaman budaya.

\section{Membangun Tiga Aspek Mutual}

Tiga aspek mutual yaitu membangun saling percaya (mutual trust), memahami saling pengertian (mutual understanding), dan menjunjung sikap saling menghargai (mutual respect). Tiga hal ini sebagai konsekuensi logis akan kemajemukan, maka diperlukan pendidikan yang berorientasi kepada kebersamaan dan penanaman sikap toleran, demokratis, serta kesetaraan hak.

Implementasi menghargai perbedaan dimulai dengan sikap saling menghargai dan menghormati dengan tetap menjunjung tinggi rasa persatuan dan persaudaraan. Hal tersebut dalam Islam lazim disebut tasamuh (toleransi). ${ }^{8}$ Ayat-ayat Al-Qur'an yang menekankan akan pentingnya saling percaya, pengertian, dan menghargai orang lain adalah: Pertama, ayat yang menganjurkan untuk menjauhi berburuk sangka dan mencari kesalahan orang lain yaitu Surat al-Hujurat [49] 12 sebagai berikut,

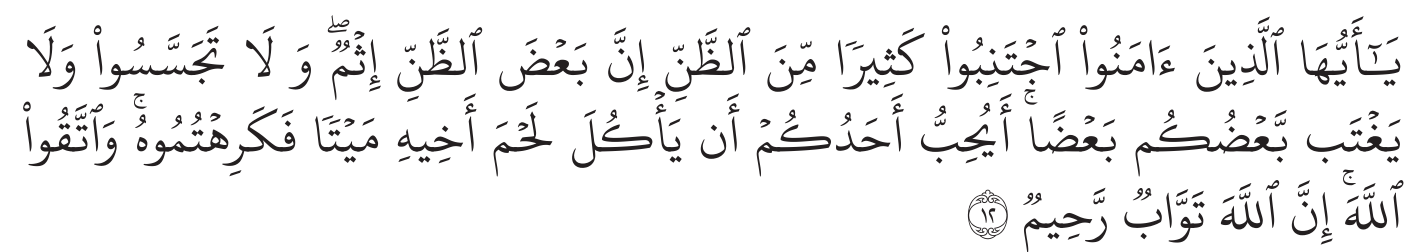

Hai orang-orang yang beriman, jauhilah kebanyakan dari prasangka, sesungguhnya sebagian prasangka itu adalah dosa dan janganlah kamu mencari-cari kesalahan orang lain dan janganlah sebahagian kamu menggunjing sebahagian yang lain.

Dalam Tafsir Al-Misbah yang dikarang oleh M. Quraish Shihabmenjelaskan bahwa: Hai orang-orang yang beriman, jauhilah dengan sungguh-sungguh banyak dari dugaan, yakni prasangka buruk terhadap manusia yang tidak memiliki indikator memadai, sesungguhnya sebagaian dugaan, yakni yang tidak memiliki indikator itu, adalah dosa. Selanjutnya, karena tidak jarang prasangka buruk mengundang upaya mencari tahu, maka ayat di atas melanjutkan bahwa: Dan janganlah kamu mencari-cari kesalahan orang lain yang justru ditutupi

\footnotetext{
${ }^{7}$ Sanapiah Faisal, Sosiologi Pendidikan,...hal. 379.

${ }^{8}$ Mundzier Suparta, Islamic Multicultural Education: Sebuah Refleksi atas Pendidikan Agama Islam di Indonesia, Jakarta: al-Ghazali Center, 2008, hal. 55-57.
} 
oleh pelakunya serta jangan juga melangkah lebih luas. Yakni sebagian kamu menggunjing, yakni membicarakan aib sebagian yang lain. Sukakah salah seorang diantara kamu memakan daging saudaranya yang sudah mati? Maka, tentulah itu jika disodorkan kepada kamu, kamu telah merasa jijik kepadanya dan akan menghindari memakan daging saudara sendiri itu. Karena itu, hindarilah pergunjingan karena ia sama dengan memakan daging saudaranya yang telah meninggal dunia dan bertaqwalah kepada Allah, yakni hindari siksa-Nya dan menjauhi larangan-Nya serta bertaubatlah atas aneka kesalahan, sesungguhnya Allah Maha Penerima taubat lagi Maha Penyayang".

\section{Terbuka dalam Berfikir}

Pendidikan seyogyanya memberi pengetahuan baru tentang bagaimana berfikir dan bertindak, bahkan mengadopsi dan beradaptasi terhadap kultur baru yang berbeda, kemudian direspons dengan fikiran terbuka dan tidak terkesan eksklusif. Peserta didik didorong untuk mengembangkan kemampuan berfikir sehingga tidak ada kejumudan dan keterkekangan dalam berfikir. Penghargaan Al-Qur'an terhadap mereka yang mempergunakan akal, bisa dijadikan bukti representatif bahwa konsep ajaran Islampun sangat responsif terhadap konsep berfikir secara terbuka. Salah satunya ayat yang menerangkan betapa tingginya derajat orang yang berilmu yaitu Surat al-Mujadalah [58] 11, Allah berfirman yang berbunyi:

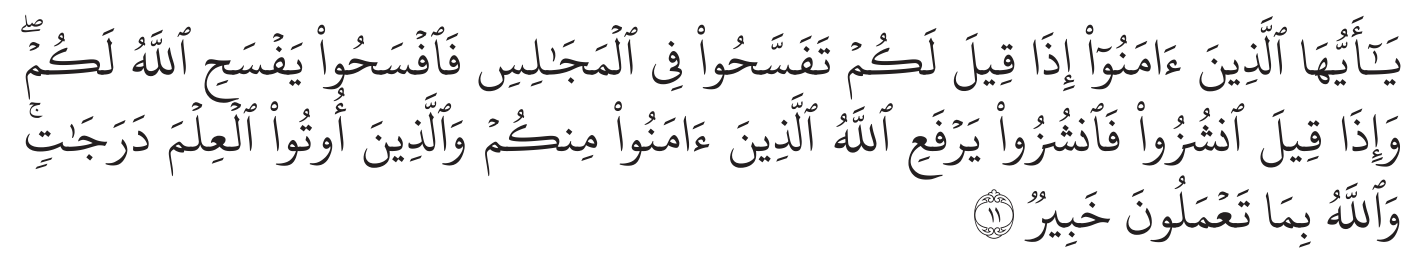

Hai orang-orang yang beriman, apabila dikatakan kepadamu: "Berlapang-lapanglah dalam majelis", maka lapangkanlah, niscaya Allah akan memberi kelapangan untukmu. Dan apabila dikatakan: "Berdirilah kamu, maka berdirilah, niscaya Allah akan meninggikan orang-orang yang beriman di antaramu dan orang-orang yang diberi ilmu pengetahuan beberapa derajat. Dan Allah Maha Mengetahui apa yang kamu kerjakan. (QS al-Mujadalah [58] 11).

M. Quraish Shihab ketika menafsirkan ayat ini menjelaskan bahwa: Ayat di atas merupakan tuntunan akhlak dan memberi tuntunan bagaimana menjalin hubungan harmonis dalam satu majelis. Allah berfirman: Hai orang-orang yang

${ }^{9}$ M. Quraish Shihab, Tafsir Al-Misbah Pesan, Kesan dan Keserasian Al-Qur'an Vol. 12, Jakarta: Lentara Hati, 2002, hal. 608-609. 
beriman, apabila dikatakan kepada kamu oleh siapapun: "Berlapang-lapanglah, yakni berupayalah dengan sungguh-sungguh walau dengan memaksakan diri untuk memberi tempat orang lain, dalam majelis-majelis, yakni satu tempat, baik tempat duduk maupun bukan untuk duduk, apabila di minta kepada kamu agar melakukan itu maka lapangkanlah tempat itu untuk orang lain itu dengan sukarela. Jika kamu melakukan hal tersebut, niscaya Allah akan melapangkan segala sesuatu buat kamu dalam hidup ini. Dan apabila dikatakan: "Berdirilah kamu ke tempat yang lain, atau untuk diduduki tempatmu buat orang yang lebih wajar, atau bangkitlah untuk melakukan sesuatu seperti untuk shalat dan berjihad, maka berdiri dan bangkit-lah, Allah akan meninggikan orang-orang yang beriman di antara kamu, wahai yang memperkenankan tuntunan ini, dan orangorang yang diberi ilmu pengetahuan beberapa derajat kemuliaan di dunia dan di akhirat dan Allah terhadap apa yang kamu kerjakan sekarang dan masa datang Maha Mengetahui". ${ }^{10}$

\section{Resolusi Konflik dan Rekonsiliasi Nirkekerasan}

Konflik dalam berbagai hal harus dihindari, dan pendidikan harus mengfungsikan diri sebagai satu cara dalam resolusi konflik. Adapun resolusi konflik belum cukup tanpa rekonsiliasi, yakni upaya perdamaian melalui sarana pengampunan atau memaafkan (forgiveness). Pemberian ampun atau maaf dalam rekonsiliasi adalah tindakan tepat dalam situasi konflik komunal. Dalam ajaran Islam, seluruh umat manusia harus mengedepankan perdamaian, cinta damai dan rasa aman bagi seluruh makhluk. Juga secara tegas Al-Qur’an menganjurkan untuk memberi maaf, membimbing kearah kesepakatan damai dengan cara musyawarah, duduk satu meja dengan prinsip kasih sayang. Hal ini telah dijelaskan dalam Surat asy-Syuura [42] 40 sebagai berikut,

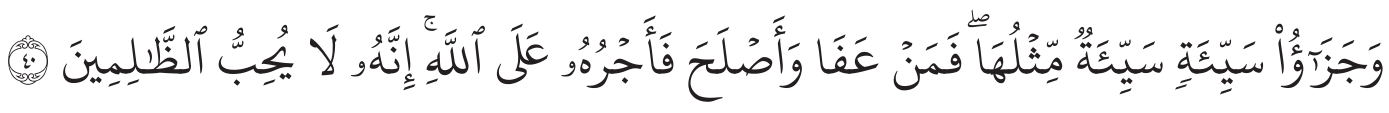

Dan balasan suatu kejahatan adalah kejahatan yang serupa, maka Barang siapa memaafkan dan berbuat baik maka pahalanya atas (tanggungan) Allah. Sesungguhnya Dia tidak menyukai orang-orang yang zalim.

M. Quraish Shihab dalam Tafsir Al-Misbah diterangkan bahwa: Orangorang yang apabila mereka diperlakukan dengan zalim-mereka-yakni mereka sendiri dengan kekuatan mental dan fisiknya, mereka selalu saling membela dengan pembelaan yang sesuai dengan kondisi yang mereka hadapi sehingga penganiayaan tersebut tidak berlanjut, pelakunyapun menjadi jera, dan balasan

${ }^{10}$ M. Quraish Shihab, Tafsir Al-Misbah Pesan, Kesan dan Keserasian Al-Qur'an Vol. 13, Jakarta: Lentara Hati, 2002 hal. 448-489. 
suatu kejahatan, apapun kejahatan itu, adalah kejahatan yang serupa lagi seimbang. Ini demi wujudnya keadilan dan hilangnya dendam bagi yang dizalimi. Selanjutnya, karena syarat keserupaan dimaksud tidak mudah diterapkan, ayat di atas melanjutkan bahwa: Maka barang siapa memaafkan, yakni sedikitpun tidak menuntut haknya, atau mengurangi tuntutannya sehingga tidak terjadi pembalasan yang serupa itu, lalu menjalin hubungan harmonis dan berbuat baik terhadap orang yang pernah menganiayanya secara pribadi, maka pahalanya dia akan peroleh atas jaminan dan tanggungan Allah. Hanya Allah yang mengetahuai betapa hebat dan besarnya pahala itu. Anjuran memaafkan dan berbuat baik itu adalah agar tidak terjadi pelampauan batas atau penempatan sesuatu bukan pada tempatnya karena sesungguhnya Dia Yang Maha Esa dan Kuasa itu tidak menyukai, yakni tidak melimpahkan rahmat bagi, orang-orang zalim yang mantap kezalimannya sehingga melanggar hak-hak pihak lain". ${ }^{11}$

Apabila terjadi perselisihan, maka Islam menawarkan jalur perdamaian melalui dialog untuk mencapai mufakat. Hal ini tidak membedakan ras, warna kulit, etnik, kebudayaan dan bahkan agama. ${ }^{12}$ Kesadaran terhadap kehidupan yang multikultural pada akhirnya akan menjelma menjadi suatu kesatuan yang harmonis yang memberi corak persamaan dalam spirit dan mental. ${ }^{13}$ Untuk memperoleh keberhasilan bagi terealisasinya tujuan mulia yaitu perdamaian dan persaudaraan abadi di antara orang-orang yang pada realitasnya memang memiliki agama dan iman berbeda, perlulah kiranya adanya keberanian mengajak pihak-pihak yang berkompenten melakukan perubahan-perubahan di bidang pendidikan terutama sekali melalui kurikulumnya yang berbasis keanekaragaman.

Nabi Muhammad mengajarkan untuk selalu menghormati dan menghargai orang lain, baik dari golongan yang berbeda atau bahkan agama yang sama sekali berbeda. Dalam pandangan Islam yang berperan sebagai wahyu, ajaran, serta nilai, tidak dipungkiri bahwa Islam adalah agama yang begitu toleran dan merupakan rahmat bagi semesta alam. Ajaran-ajaran Islam menuntun manusia untuk menjunjung tinggi harkat dan martabat manusia. Menghormati setiap hak asasi manusia, berjalan bersama, dan saling menolong dalam kebaikan. Dengan pendidikan multikultural diharapkan setiap individu atau kelompok bisa menerima dan menghargai setiap perbedaan, hidup berdampingan dengan

${ }^{11}$ M. Quraish Shihab, Tafsir Al-Misbah Pesan, Kesan dan Keserasian Al-Qur'an Vol. 12, Jakarta: Lentara Hati, 2002, hal. 178-179.

${ }^{12}$ Mundzier Suparta, Islamic Multicultural Education: Sebuah Refleksi atas Pendidikan Agama Islam di Indonesia,...hal. 59.

${ }^{13}$ Asma Hasan Fahmi, Sejarah dan Filsafat Pendidikan Islam, cet. ke-1. Jakarta: Bulan Bintang, 1979, hal. 11. 
damai dan tenang walaupun berbeda-beda, sehingga terbentuk sebuah negara dan bangsa yang damai dan sejahtera.

\section{Pendekatan Qur'ani Pendidikan Multikulturalisme}

Dalam konteks teoritis, belajar dari model-model pendidikan multikultural yang pernah ada dan sedang dikembangkan oleh negara-negara maju dikenal dengan lima pendekatan, yaitu; Pertama, pendekatan pendidikan yang mengajarkan perbedaan-perbedaan kebudayaan atau multikulturalisme penuh dengan kebaikan. Kedua, pendekatan pendidikan yang mengajarkan perbedaan-perbedaan kebudayaan atau pemahaman kebudayaan. Ketiga, pendekatan pendidikan bagi pluralism kebudayaan. Keempat,pendekatan pendidikan yang mengajarkan dwi-budaya. Kelima, pendekatan pendidikan multikultural sebagai pengalaman moral manusia. ${ }^{14}$

Sementara itu pendekatan Qur'ani pendidikan multikulturalisme dalam Islam dapat dirujukkan minimal dari tiga katagori, yakni pertama perspektif teologis, kedua perspektif historis dan ketiga perspektif sosiologis. ${ }^{15}$ Berikut ini akan dijelaskan ketiga pendekatan Qurani pendidikan Multikulturalisme sebagai berikut:

\section{Pendekatan dalam Perspektif Teologis}

Pendekatan Qur'ani pendidikan multikulturalisme dalam perspektif teologis Islam dapat ditemukan dalam banyak ayat Al-Qur'an. Sebagaimana diketahui bahwa kemajemukan yang ada di dunia ini adalah sebuah kenyataan yang sudah menjadi sunnatullah (ketentuan Allah). Di dalam Al-Qur'an surat al-Hujarat ayat 13, Allah menyebutnya bahwa kemajemukan adalah kehendak-Nya. Perbedaan-perbedaan yang ada di sekitar kehidupan manusia telah tertulis dalam Al-Qur'anul Karim sebagaimana Allah SWT. telah berfirman dalam surat al-Hujurat [49] 13 sebagai berikut,

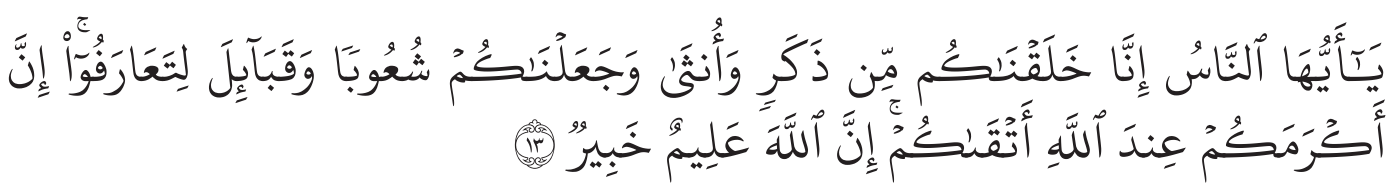

Hai manusia, sesungguhnya Kami menciptakan kamu dari seorang laki-laki dan seorang perempuan dan menjadikan kamu berbangsa bangsa dan bersuku-suku supaya kamu saling kenal-mengenal. Sesungguhnya

\footnotetext{
${ }^{14}$ Choirul Mahfud, Pendidikan Multikultural,...hal. 213-214.

${ }^{15}$ Muhaimin, Strategi Belajar Mengajar Pendidikan Agama Islam, Surabaya: CV. Citra Media, Cet. Ke-1, 1996, hal. 1.
} 
orang yang paling mulia diantara kamu di sisi Allah ialah orang yang paling taqwa diantara kamu. Sesungguhnya Allah Maha mengetahui lagi Maha Mengenal (QS al-Hujurat [49] 13).

Dari ayat 13 surat Al-Hujurat tersebut, sangat tegas bahwa Islam pada dasarnya menganggap sama setiap manusia, yakni tercipta dan dilahirkan dari sepasang orang tua mereka (laki-laki dan perempuan), kemudian keterlahiran ini sendiri mempunyai tujuan untuk saling mengenal dan memahami karakter masing-masing kelompok setelah manusia ini menjadi kelompok yang berbeda.

\section{Pendekatan dalam Perspektif Historis}

Pendekatan Qurani pendidikan multikulturalisme perspektif historis dalam Islam, dapat dirujuk langsung oleh sistem kenegaraan yang diterapkan Nabi Muhammad SAW dengan Piagam Madinahnya. Piagam Madinah ini adalah konsesi (perlawanan) atas Hijrah Nabi Muhammad SAW pada tahun 622 Masehi yang menemukan kondisi sosiologis Madinah berbeda dengan di Makkah. Piagam ini menetapkan seluruh penduduk Madinah memperoleh status yang sama atau persamaan dalam kehidupan. Prinsip Demokrasi, kesetaraan, dan keadilan terkandung dalam piagam Madinah pada pasal 16 dan 46 berikut:

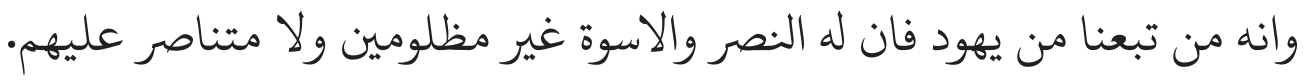

Pasal 16: Sesungguhnya orang Yahudi yang mengikuti kita berhak atas pertolongan dan santunan, sepanjang (mukminin) tidak terzalimi dan ditentang olehnya.

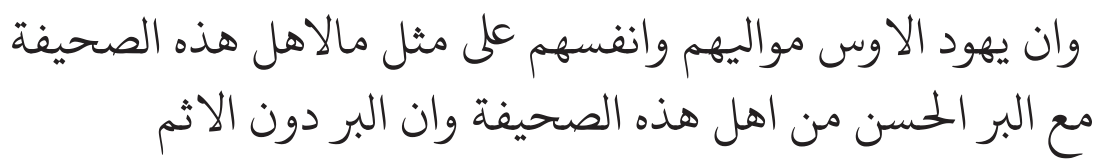

Pasal 46: Kaum Yahudi Al-Aws, sekutu dan diri mereka memiliki hak dan kewajiban seperti kelompok lain pendukung piagam ini, dengan perlakuan yang baik dan penuh dari semua pendukung piagam ini. Sesungguhnya kebaikan (kesetiaan) itu berbeda dari kejahatan (pengkhianatan). Setiap orang bertanggung jawab atas perbuatannya. Sesungguhnya Allah paling membenarkan dan memandang baik isi piagam ini. ${ }^{16}$

${ }^{16}$ Suyuthi Pulungan, Prinsip-Prinsip Pemerintahan dalam Piagam Madinah Ditinjau Dari Pandangan Al-Qur'an, Jakarta: PT. Raja Grafindo, Cet. Ke-1, 1994, hal.150. 
Piagam Madinah (Babasa Arab: صحيفة المدينه, shahifatul madinah) juga dikenal dengan sebutan Konstitusi Madinah, ialah sebuah dokumen yang disusun oleh Nabi Muhammad SAW' yang merupakan suatu perjanjian formal antara dirinya dengan semua suku-suku dan kaum-kaum penting di Yasrib (kemudian bernama Madinah) pada tahun 622. Dokumen tersebut disusun sejelas-jelasnya dengan tujuan utama untuk menghentikan pertentangan sengit antara Bani'Aus dan Bani Khazraj di Madinah. Untuk itu dokumen tersebut menetapkan sejumlah hak-hak dan kewajiban-kewajiban bagi kaum Muslim, kaum Yahudi, dan komunitas-komunitas piagam Madinah; sehingga membuat mereka menjadi suatu kesatuan komunitas, yang dalam bahasa Arab disebut ummah. ${ }^{17}$

Dua pasal Piagam Madinah di atas menunjukkan bahwa Nabi Muhammad SAW memiliki kepedulian tinggi terhadap persoalan demokrasi, kesetaraan dan keadilan antaretnis, antarras dan antaragama. Selain itu, dua pasal Piagam Madinah juga mengandung pesan moral bahwa Nabi Muhammad SAW menolak adanya diskriminasi, hegemoni, dan dominasi dalam kehidupan masyarakat yang majemuk. Dengan demikian, dari sudut perspektif moderen, dua pasal di atas dapat menjadi inspirasi untuk membangun masyarakat multikultural. Sementara itu, dari sudut perspektif pendidikan, dua pasal tersebut dapat dijadikan sebagai dasar untuk mengembangkan pendidikan multikultural. ${ }^{18}$

\section{Pendekatan dalam Perspektif Sosiologis}

Pendekatan Qur'ani pendidikan multikulturalisme perspektif sosiologis terdapat dalam intern umat Islam sendiri. Hal ini dapat dilihat dalam praktek keberagamaan umat Islam di seantero dunia Islam. Secara internal umat Islam memiliki keanekaragaman madzhab fiqih, tasawuf dan kalam. Dalam bidang fiqih umat Islam Indonesia mengenal adanya madzhab lima, dari Imam Syafii dengan qaul jadid dan qadimnya, Imam Hanaf, Hambali, Abu Hanifah dan Imam Ja'far. Begitu juga dalam ilmu kalam, Imam al-Asy'ari, dan Maturidy disebut sebagai penggagas Ahlussunnah (Sunni), Wasil bin Atho' dengan Mu'tazilahnya, Khawarij, Murji’ah juga ada Syiah dan para pendukung Imam Ali di belakangnya.

Kemajemukan intern umat Islam juga ditemukan dalam praktek pengelompokan sosial, politik kepartaian serta model pendidikannya. Dinasti dan kekhalifahan yang pernah ada dalam sejarah Islam seperti Dinasti Mughal, Fathimiyah, Abasiah dan terakhir dinasti Turki Usmani adalah contoh konkret tentang keragaman yang ada dalam Islam. Dari sudut multikulturalisme internal ini, pluralisme identitas kultural keagamaan bagi masyarakat muslim, bukanlah

${ }^{17}$ Zuhairi Misrawi, Madinah (Kota Suci, Piagam Madinah, dan Teladan Muhammad SAW, Jakarta: PT Kompas Media Nusantara, 2009, hal. 459.

${ }^{18}$ Abdullah Aly, Pendidikan Islam dan Tantangan Globalisasi,...hal. 112-113. 
menjadi sekedar fakta, lebih dari itu, multikulturalisme telah menjadi semangat, sikap hidup dan pendekatan dalam menjalani kehidupan dengan orang lain. ${ }^{19}$

Dalam banyak artikel maupun karya yang ditulis Abdurrahman Wahid, ${ }^{20}$ beliau sering menggunakan dalil Al-Qur'an yang menekankan pada konsep pendidikan multikultural. Dari berbagai macam dalil yang sering digunakan ialah Al-Qur’an surat Al-Hujarat [49] 11 sebagai berikut,

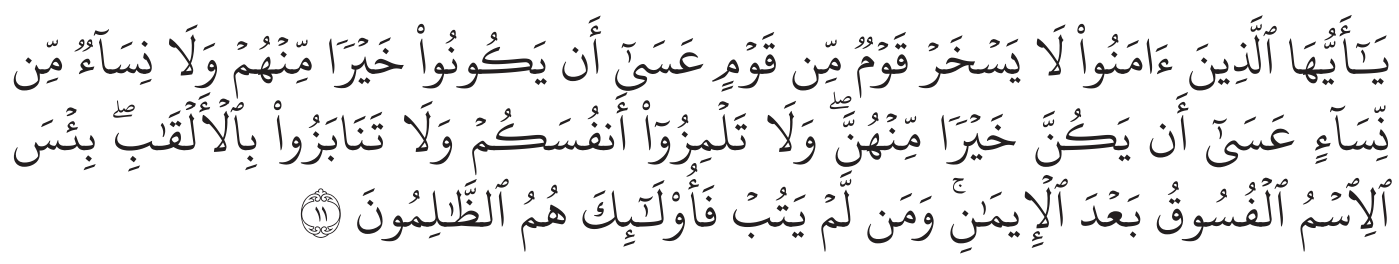

Hai orang-orang yang beriman, janganlah sekumpulan orang laki-laki merendahkan kumpulan yang lain, boleh jadi yang ditertawakan itu lebih baik dari mereka. Dan jangan pula sekumpulan perempuan merendahkan kumpulan lainnya, boleh jadi yang direndahkan itu lebih baik. Dan janganlah suka mencela dirimu sendiri dan jangan memanggil dengan gelaran yang mengandung ejekan. Seburuk-buruk panggilan adalah (panggilan) yang buruk sesudah iman dan barangsiapa yang tidak bertobat, maka mereka itulah orang-orang yang zalim. (QS al-Hujarat [49] 11).

Al-Qur'an mengingatkan dengan tegas dalam ayat di atas sebagai antisipasi kemungkinan timbulnya sikap dan budaya saling mencemooh dan merendahkan antara kelompok yang satu dengan yang lain. Karena tindakan mencemooh dan mengejek, serta merendahkan orang, apalagi kelompok lain, merupakan cikal dan sumber konflik sosial yang potensial. ${ }^{21}$

Jadi, isi pendekatan dalam pembelajaran harus menghargai perbedaan dan tidak diskriminatif. Misalnya, ketika mengajarkan sebuah materi fiqih perlu memasukkan pendapat atau pemikiran dari banyak ulama, agar siswa mengetahui dalam ilmu itu dikembangkan dari beragam pendapat karena perbedaan pendapat itu tidak bisa dihindari dan dihilangkan dalam kehidupan ini. ${ }^{22}$

${ }^{19}$ Zakiyuddin Baidhawy, Reinvensi Islam,...hal. 215-217.

${ }^{20}$ Abdurrahman Wahid, Islamku Islam Anda Islam Kita, Jakarta: The Wahid Institute, 2006, hal. 102-134.

${ }^{21}$ M. Amin Abdullah, Dinamika Islam Kultural; Pemetaan Wacana Keislaman Kontemporer, Bandung: Mizan, Cet. Ke-1, 2000, hal. 77.

${ }^{22}$ Zubaedi et al., Hermeneia; Jurnal Kajian Islam Interdisipliner,...hal. 14. 


\section{Penerapan Pendidikan Multikulturalisme yang Qur'ani}

Penerapan Qur'ani Pendidikan Multikulturalisme sangatlah penting. Dalam pembahasan berikut penulis akan mengambil beberapa surat yang berkaitan dengan penerapan pendidikan multikulturalisme dalam Al-Qur'an dan dijelaskan atau diterangkan dalam Tafsir Al-Misbah.

\section{Penerapan Pendidikan Multikultural yang terkait dengan Akidah}

Penerapan pendidikan multikultural yang terkait dengan akidah, berdasarkan Al-Qur'an selalu mengajak umat manusia sejak zaman lampau, kini dan di masa mendatang agar masuk Islam dan menolak pemikiran yang mengagung-agungkan manusia yang dianggap "dewa" atau mendewakan materi, seperti akidah yang menekankan pada material. Juga bisa menolak pemikiran yang berbau syirik. Sebagaimana kita ketahui bahwa manusia tidak bisa menciptakan manusia, hanya Tuhan yang Maha Pencipta dan Pemberi rezeki. Semua makhluk hidup yang berkeliaran di muka bumi pada hakekatnya adalah lemah dalam menentukan hidupnya sendiri, mereka sebenarnya menjalani garis yang telah ditetapkan namun dituntut selalu berusaha dalam mengarungi kehidupan yang penuh dengan misteri ini. Akidah yang Qur'ani berpegang teguh dan menghargai fungsi akal, sikap sederhana sebagai jalan hidupnya. Kebijaksanaan sebagai metode dakwah yang disampaikan, ilmu pengetahuan sebagai pertimbangan, referensi dan langkah-langkah untuk pembinaan pikiran seseorang dan perkembangan peradaban. Berikut ayat-ayat al-Qur'an yang mengajarkan tentang pengembangan aqidah antara lain: Surat al-An'am [6] 108 sebagai berikut:

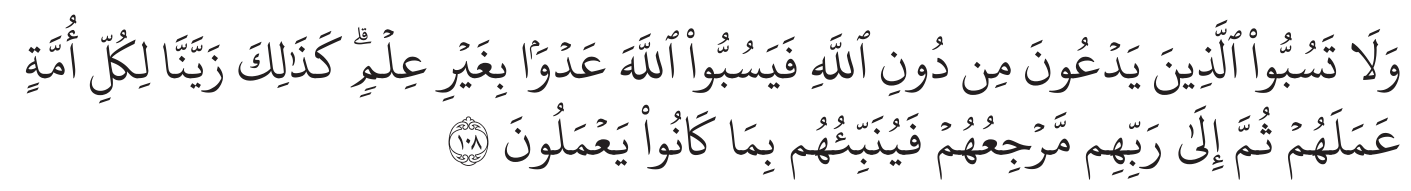

Dan janganlah kamu memaki sembahan-sembahan yang mereka sembah selain Allah, karena mereka nanti akan memaki Allah dengan melampaui batas tanpa pengetahuan. Demikianlah Kami jadikan setiap umat menganggap baik pekerjaan mereka. Kemudian kepada Tuhan merekalah kembali mereka, lalu Dia memberitakan kepada mereka apa yang dahulu mereka kerjakan. (QS al-An'am [6] 108).

M. Quraish Shihab dalam Tafsir Al-Misbah menerangkan bahwa: Tidak ada paksaan dalam menganut agama. Mengapa ada paksaan, padahal Dia tidak membutuhkan sesuatu; Mengapa ada paksaan, padahal sekiranya Allah menghendaki, niscaya kamu dijadikan-Nya satu umat (saja) (QS.al-Maidah/5: 48). 
Perlu dicatat bahwa yang dimaksud dengan tidak ada paksaan dalam menganut agama adalah menganut akidahnya. Ini berarti jika seseorang telah memilih satu aqidah, katakan saja aqidah Islam, dia terikat dengan tuntunan-tuntunannya, di berkewajiban melaksanakan perintahnya. Dia terancam sanksi bila melanggar ketetapannya. Dia tidak boleh berkata, "Allah telah memberi saya kebebasan untuk shalat atau tidak, berzina atau nikah." Karena, bila dia telah menerima akidahnya, dia harus melaksanakan tuntunannya. Kembali kepada penegasan ayat ini, tidak ada paksaan dalam menganut keyakinan agama; Allah menghendaki agar setiap orang merasakan kedamaian. Agama-Nya dinamai Islam, yakni damai. Kedamaian tidak dapat diraih kalu jiwa tidak damai. Paksaan menyebabkan jiwa tidak damai sehingga tidak ada paksaan dalam menganut keyakinan agama Islam". ${ }^{23}$

Ayat di atas dengan tegas menjelaskan bahwa tidak ada paksaan untuk memeluk agama. Maksud ayat ini kita tidak boleh memaksa seseorang untuk memeluk agama Islam. Allah akan memberi petunjuk dan membuka pintu hati seseorang yang ingin memeluk agama Islam.

Menurut Tafsir Al-Misbah, yang ditekankan disini adalah hakikat aqidah, bukan fanatisme golongan atau bangsa. Dan, hal ini tentu saja sebelum diutusnya Nabi Muhammad Saw. Adapun sesudah diutusnya beliau, maka bentuk iman yang terakhir ini sudah ditentukan. Ayat ini menetapkan bahwa siapa saja diantara mereka yang beriman kepada Allah dan hari akhir serta beramal saleh, mereka akan mendapatkan pahala di sisi Tuhannya, mereka tidak merasa khawatir dan tidak bersedih hati. Hal tersebut sejalan dengan pemikiran pendidikan multicultural yang merupakan sebuah proses pengembangan, yaitu sebuah proses yang tidak dibatasi oleh ruang, waktu, dan relasinya.

\section{Penerapan Pengembangan Potensi Intelektual Manusia}

Manusia sebagai makhluk ciptaan Tuhan yang paling sempurna tercantum dalam Al-Qur'an surat at-Tin ayat 5. Secara fisik, manusia memiliki struktur tubuh yang sangat sempurna, ditambah lagi dengan pemberian akal, maka ia adalah makhluk jasadiyah dan ruhaniyah. Akal yang dianugerahkan kepada manusia memiliki tingkatan kecerdasan yang berbeda-beda.

Banyak orang meyakini bahwa orang yang cerdas adalah orang yang memiliki kemampuan Intelligence Quotient (IQ) yang tinggi, namun pada kenyataannya, tidak semua orang yang memiliki kemampuan IQ yang tinggi itu memiliki kemampuan adaptasi, sosialisi, pengendalian emosi, dan kemampuan

${ }^{23}$ M. Quraish Shihab, Tafsir Al-Misbah Pesan, Kesan dan Keserasian Al-Qur'an Vol. 1, Jakarta: Lentara Hati, 2002 hal. 668-669. 
spiritual. Banyak orang yang memiliki kecerdasan IQ, namun ia tidak memiliki kemampuan untuk bergaul, bersosialisai dan membangun komunikasi yang baik dengan orang lain. Banyak juga orang yang memiliki kemampuan IQ, tetapi ia tidak memiliki kecerdasan dalam melakukan hal-hal yang dapat menentukan keberhasilannya di masa depan, prioritas-prioritas apa yang mesti dilakukan untuk menuju sukses dirinya.

Berikut ayat-ayat al-Qur'an yang berkaitan dengan pengembangan potensi intelektual manusia antara lain: Surat Az-Zumar [39] 9 sebagai berikut,

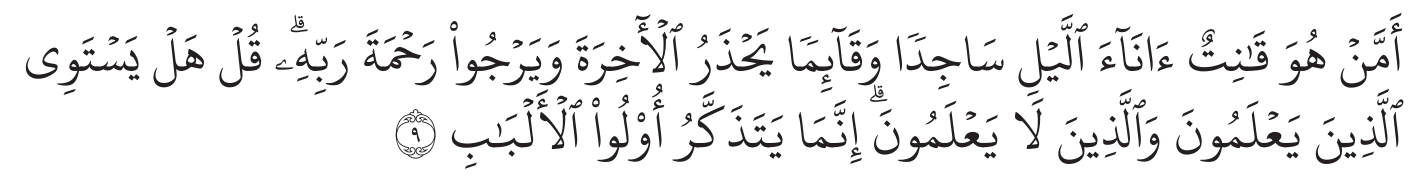

(Apakah kamu hai orang musyrik yang lebih beruntung) ataukah orang yang beribadat di waktu-waktu malam dengan sujud dan berdiri, sedang ia takut kepada (azab) akhirat dan mengharapkan rahmat Tuhannya? Katakanlah: "Adakah sama orang-orang yang mengetahui dengan orangorang yang tidak mengetahui?» Sesungguhnya orang yang berakallah yang dapat menerima pelajaran (QS al-Zumar [39] 9)

M. Quraish Shihab dalam Tafsir Al-Misbah menafsirkan ayat di atas bahwa: "Perumpaan orang yang menyeru orang-orang kafir kepada kebenaran, adalah seperti penggembala yang berteriak. Rasul atau para juru dakwah diibaratkan dengan penggembala, sedang para pengikut tradisi yang usang itu, seperti binatang. Mereka yang diajak itu sama dengan binatang, keduanya mendengar suara panggilan dan teriakan tetapi tidak memahami atau tidak dapat memanfaatkan suara panggilan itu. Ayat ini juga berarti, orang-orang itu dalam ibadah dan doa mereka kepada tuhan-tuhan mereka, seperti penggembala yang berteriak kepada binatangnya yang tidak mendengar. Di sini orang-orang kafir itu diibaratkan dengan penggembala dan Tuhan-Tuhan yang mereka sembah diibaratkan serupa dengan binatang-binatang. Orang-orang kafir yang mempertahankan tradisi using itu pada hakikatnya tuli, tidak memfungsikan alat pendengaran mereka sehinggga mereka tidak dapat mendengar bimbingan; bisu, tidak memfungsikan lidah mereka sehinggga mereka tidak dapat bertanya dan berdialog, dan buta, tidak memfungsikan mata mereka sehingga mereka tidak dapat melihat tandatanda kebesaran Allah, dan akhirnya mereka tidak dapat menggunakan alatalat itu untuk mendengar, melihat, dan berfikir sesuai dengan yang dikehendaki Allah ketika menganugerahkannya, dan dengan demikian mereka tidak dapat menggunakan akalnya (yakni tidak ada kendali yang menghalanginya melakukan keburukan, kesalahan, dan mengikuti tradisi orang tua walau mereka sesat 
atau keliru). Orang-orang mukmin dilarang mengikuti mereka.". Jadi orang yang berilmu pengetahuan dapat memiliki derajat yang lebih tinggi dibandingkan orang yang tidak memiliki ilmu pengetahuan di sisi Allah. Penghargaan Allah tersebut sesuai dengan dasar pelaksanaan pendidikan multikultural untuk mengembangkan potensi intelektual yang dimiliki manusia.

\section{Penerapan Pengembangan Prilaku Baik terhadap Sesama Manusia}

Ajaran Al-Qur'an tentang cinta kasih sayang dan berbuat kebaikan telah tertutupi oleh berita-berita yang mengesankan bahwa Islam bukan agama damai tetapi agama yang mengajarkan kekerasan dan menjadi sumber inspirasi terorisme. Jauh dari semua itu, Al-Qur'an mengajarkan kepada satu Tuhan dan satu kesatuan umat manusia dengan perbuatan baik dan saling kasih sayang. Berikut ini akan kami jelaskan beberapa ayat tentang berbuat kebaikan dan kasih sayang yang terdapat di dalam Al-Qur'an. Al-Qur'an menekankan bahwa ketakwaan bukan dinilai hanya dengan kesalehan ritual semata melainkan dalam bentuk amal saleh dan kasih sayang. Al-Qur'an menjelaskan bahwa parameter suatu keyakinan dan ibadah yang benar adalah dapat mewujudkan hidup yang penuh kebaikan dan kasih sayang.

Berikut ayat-ayat Al-Qur'an yang mengajarkan tentang pengembangan potensi intelektual manusia antara lain: Surat Al-Baqarah[2] 148 sebagai berikut,

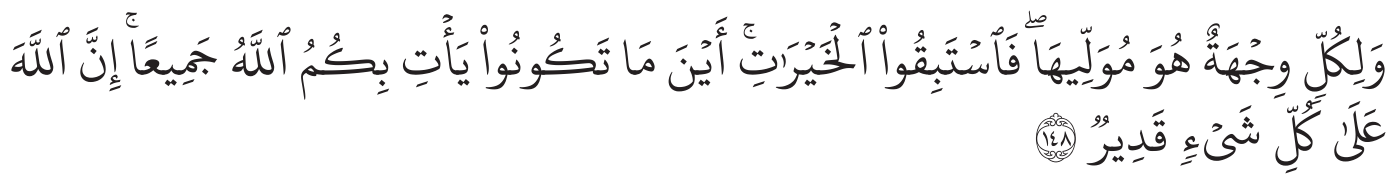

Dan bagi tiap-tiap umat ada kiblatnya (sendiri) yang ia menghadap kepadanya. Maka berlomba-lombalah (dalam membuat) kebaikan. Di mana saja kamu berada pasti Allah akan mengumpulkan kamu sekalian (pada hari kiamat). Sesungguhnya Allah Maha Kuasa atas segala sesuatu.

Dalam Tafsir Al-Misbah diterangkan: "Bagi setiap umat ada kiblatnya sendiri-sendiri yang ia menghadap kepadanya. Kaum muslimin pun ada kiblatnya, tetapi kiblat kaum muslimin ditetapkan langsung oleh Allah SWT. Maka, berlomba-lombalah kamu, wahai kaum muslimin, satu dengan yang lain dalam berbuat kebaikan. Atau ayat ini bermakna: Bagi setiap umat ada kiblatnya sendiri yang ia menghadap kepadanya, sesuai dengan kecenderungan atau keyakinan masing-masing. Kalaulah mereka dengan mengarah ke kiblat masing-masing bertujuan untuk mancapai ridha Allah dan melakukan kebajikan, maka wahai

${ }^{24}$ M. Quraish Shihab, Tafsir Al-Misbah Pesan, Kesan dan Keserasian Al-Qur’an Vol. 1, hal. 460-461. 
kaum muslimin berlomba-lombalah kamu dengan mereka dalam berbuat aneka kebaikan. Dalam kehidupan dunia kalian berselisih, tetapi ketahuilah bahwa kamu semua akan mati dan di mana saja kamu berada pasti Allah akan mengumpulkan kamu sekalian pada Hari Kiamat untuk Dia beri putusan. Sesungguhnya Allah Mahakuasa atas segala sesuatu". ${ }^{25}$

Ayat ini menurut Tafsir Al-Misbah, bahwa semua akan mati dan di mana saja berada pasti Allah akan mengumpulkan pada hari Kiamat untuk Dia beri putusan, dengan ini manusia nanti akan dimintai pertanggung jawaban atas perbuatannya selama di dunia. Untuk itu manusia diperintahkan untuk berlomba-lombalah dalam berbuat kebaikan, agar mendapatkan ridha dari Allah Swt.

Pada ayat ini jelas bahwa untuk memperoleh ridha Allah, manusia diperintahkan untuk berlomba- lomba dalam melakukan kebaikan, dan hal ini sesuai dengan dasar pelaksanaan pendidikan multicultural dalam mengembangkan potensi yang dimiliki manusia, yaitu mengembangkan perilaku baik terhadap sesama manusia.

\section{Penerapan dengan Mengajarkan dan Menyerukan Perdamaian}

Perdamaian merupakan salah satu ajaran pokok dalam ajaran Islam. Perintah untuk selalu berdamai tidak hanya terdapat dalam ayat-ayat Al-Qur'an tetapi juga dicontohkan dalam kehidupan Rasulullah SAW. Sebagaimana diketahui Muhammad adalah sosok yang sangat dikenal dengan kepribadian dan budi pekertinya yang baik. Ada banyak peristiwa bersejarah yang memperlihatkan pribadi Rasulullah sebagai seorang juru damai. Bahkan jauh sebelum beliau diangkat menjadi seorang Nabi.

Diantara ayat-ayat Al-Qur'an yang mengajarkan dan menyerukan perdamain serta larangan perang dan berbuat kekerasan adalah: Surat al-Maidah [5]: 33-34 sebagai berikut,

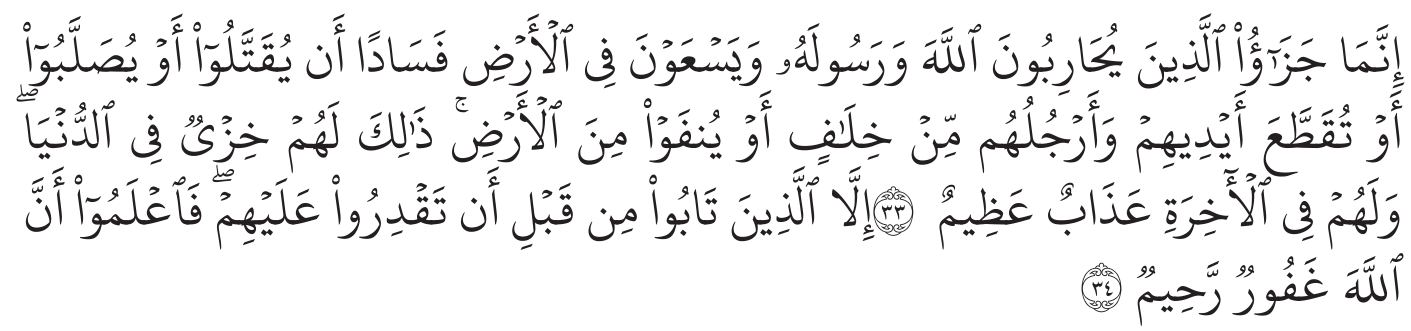

Sesungguhnya pembalasan terhadap orang-orang yang memerangi Allah dan Rasul-Nya dan membuat kerusakan di muka bumi, hanyalah mere-

${ }^{25}$ M. Quraish Shihab, Tafsir Al-Misbah Pesan, Kesan dan Keserasian Al-Qur'an Vol. 1, hal. 423-424. 
$k a$ dibunuh atau disalib, atau dipotong tangan dan kaki mereka dengan bertimbal balik, atau dibuang dari negeri (tempat kediamannya). Yang demikian itu (sebagai) suatu penghinaan untuk mereka didunia, dan di akhirat mereka beroleh siksaan yang besar (QS al-Maidah [5] 33-34)

M. Quraish Shihab ketika menafsirkan ayat ini menjelaskan bahwa: "Sesungguhnya pembalasan yang adil dan setimpal terhadap orang-orang yang memerangi Allah dan Rasul-Nya," yakni melanggar dengan angkuh terhadap ketentuan-ketentuan Rasul SAW. dan yang berkeliaran membuat kerusakan di muka bumi, yakni melakukan pembunuhan, perampokan, pencurian dengan menakut-nakuti masyarakat hanyalah mereka dibunuh tanpa ampun jika mereka membunuh, tanpa mengambil harta, atau disalib setelah dibunuh jika mereka merampok dan membunuh untuk menjadi pelajaran bagi yang lain sekaligus menentramkan masyarakat umum bahwa penjahat telah tiada, atau dipotong tangan kanan mereka karena merampas harta tanpa membunuh, dan juga dipotong kaki kiri mereka dengan bertimbal balik karen ia telah menimbulkan rasa takut dalam masyarakat, atau dibuang dari negeri tempat kediamannya, yakni dipenjarakan agar tidak menakutkan masyarakat. Ini jika ia tidak merampok harta. Yang demikian itu yakni hukuman itu sebagai suatu penghinaan untuk mereka di dunia sehingga, selain mereka, yang bermaksud jahat akan tercegah melakukan hal serupa, tetapi bukan hanya itu hukuman yang akan mereka terima $d i$ akhirat, bila mereka tidak bertaubat, mereka beroleh siksaan yang besar. Kemudian, ayat berikutnya memberi pengecualian, yakni kecuali orang-orang yang taubat di antara mereka sebelum kamu dapat menguasai yakni menangkap mereka: maka ketahuilah bahwasanya Allah Maha Pengampun lagi Maha Penyayang, dan karena itu maka hak Allah untuk menjatuhkan sanksi atas mereka yang bertaubat sebelum ditangkap itu dicabut-Nya, tetapi hak manusia yang diambil oleh para penjahat yang bertaubat itu harus dikembalikan atau dimintakan kerelaan pemilik-pemiliknya". ${ }^{26}$

Dalam ayat di atas, Nabi Muhammad diperintahkan untuk konsisten mengikuti wahyu Al-Qur'an serta sabar dalam melaksanakan tuntunan wahyu itu dan tabah menghadapi tantangan yang ditimbulkan oleh mereka yang meragukannya. Demikianlah konsep damai yang ada dalam Al-Qur'an. Semua ajaran, perintah yang ada dalam ajaran Islam sebenarnya berujung pada terciptanya perdamaian dan keadilan di dunia. Kedatangan Islam di tengah bangsa arab yang pada masa itu jelas mempunyai misi perdamaian. Bangsa Arab yang saat itu terpecah belah kedalam suku-suku dan suka berperang menjadi sebuah satu komunitas dibawah konsep keumatan. Sehingga semua manusia disamakan

${ }^{26}$ M. Quraish Shihab, Tafsir Al-Misbah Pesan, Kesan dan Keserasian Al-Qur'an Vol. 3, Jakarta: Lentara Hati, 2002 hal. 103-104. 
kedudukannya kecuali atas dasar iman. Disinilah kemudian kedatangan Islam membawa pergeseran yang cukup fundamental dalam sistem sosial bangsa Arab dari yang awalnya terpusat pada pertalian atas dasar kekeluargaan menjadi pertalian atas dasar keimanan dibawah konsep ummat.

\section{E. Kesimpulan}

Berdasarkan analisis hasil penelitian yang menggunakan metode penelitian kualitatif dan pendekatan penelitian kepustakaan (library Risearch), maka dapat disimpulkan sebagai berikut:

1. Pandangan atau tinjauan Al-Qur'an tentang pendidikan multikulturalisme pada dasarnya tidak bertentangan dengan ajaran Islam, khususnya Al-Qur'an yang menjadi sumber hukum Islam. Keanekaragaman yang ada justru menjadi kekayaan intelektual untuk dikaji, sebagaimana beberapa ayat Al-Qur'an yang menjelaskan hal tersebut. Dengan pendidikan multikultural diharapkan setiap individu atau kelompok bisa menerima dan menghargai setiap perbedaan, hidup berdampingan dengan damai dan tenang, sehingga terbentuk sebuah negara dan bangsa yang damai dan sejahtera.

2. Pandangan Al-Qur'an tentang pendidikan multikultural meliputi lima karakter, yaitu belajar hidup dalam perbedaan, membangun tiga aspek mutual (saling percaya, pengertian, dan menghargai), terbuka dalam berfikir, apresiasi dan interdependensi, serta resolusi konflik dan rekonsiliasi nirkekerasan. Dari beberapa karakteristik tersebut, diformulasikan dengan ayat-ayat Al-Qur'an dan tafsir sebagai dalil, bahwa konsep pendidikan multikultural ternyata selaras dengan ajaran-ajaran Islam dalam mengatur tatanan hidup manusia di muka bumi ini, terutama sekali dalam konteks pendidikan..

3. Islam adalah agama universal yang menjunjung tinggi nilai-nilai kemanusiaan, persamaan hak dan mengakui adanya keragaman latar belakang budaya dan kemajemukan. Pendidikan multikultural menurut Islam adalah sebuah aturan Tuhan yang tidak akan berubah, juga tidak mungkin dilawan atau diingkari. Setiap orang akan menghadapi kemajemukan di manapun dan dalam hal apapun. Ungkapan ini menggambarkan bahwa Islam sangat menghargai multikultural karena Islam adalah agama yang dengan tegas mengakui perbedaan setiap individu untuk hidup bersama dan saling menghormati satu dengan yang lainnya.

4. Kitab suci al-Qur'an yang diturunkan kepada Nabi Muhammad saw. merupakan landasan pokok agama Islam dalam semua sisi kehidupan umatnya. Al-Qur'an memberikan hujjah dan bukti penjelasan tentang prinsip-prinsip Islam yang menjadi intisari dakwah. Dengan redaksi yang jelas dan akurat, 
memberi petunjuk kepada orang Islam tentang kekuasaan Allah, agar manusia menjadi masyarakat yang ideal di dunia.

\section{Daftar Pustaka}

Abdullah, Pendidikan Multikultural di Pesantren. Yogyakarta: Disertasi pada Pascasarjana UIN Sunan Kalijaga, 2009.

Agustian, Murniati, Pendidikan Multikultural, Jakarta: Unika Atmajaya, 2015.

Ali, Muhamad. Teologi Pluralis Multikultural: Menghargai Kemajemukan

Menjalin Kebersamaan. Jakarta: Kompas, 2003, cet. ke-1

Amin, Muhamad Suma Studi Ilmu - ilmu Al Qur'an 3. Jakarta: Pustaka Firdaus, 2004.

Arikunto, Suharsimi, Prosedur Penelitian, Jakarta: Rineka Cipta, 1996.

Arifin, Muhammad, Filsafat Pendidikan Islam. Jakarta: Bina Aksara, 1987.

Ash Shidiqie dkk, Hasbi, Al-Qur'an dan Terjemahnya, Jakarta: Intermasa, 1994.

Banks, James A., Multikultural Education and Goals, New York: John Wiley \& Sons, 2010.

Baidhawi, Zakiyuddin, Pendidikan Agama Berwawasan Multikultural, Jakarta:Erlangga, 2005.

Departemen Agama Republik Indonesia, Al Quran dan Terjemahnya, Jakarta: CV. Indah Press 1994.

Faisal, Sanaipah, Metode Penelitian Pendidikan, Surabaya: Usaha Nasional, 1993.

Hernandez, Hilda, Multicultural Education: A Teacher Guide to Linking Context, Process, and Content. New Jersey: Prentice Hall, 1989

Imran, Ali, Kebijaksanaan Pendidikan Di Indonesia, Jakarta: Bumi Aksara, 2002,

Kartono, Kartini, Sistem Pendidikan Nasional, Jakarta: Pradnya Paramita, 2004,

Kymlicka, Will. Kewargaan MultikulturaL Teori Liberalmengenai Hak-hak

Minoriytas, terj. Edlina Hafmini Eddin. Jakarta: LP3ES, 2003.

Latif, Yudi, Menyemai Karakter Bangsa. Jakarta: Kompas, 2009, cet. ke-1.

Mahfud, Choirul, Pendidikan multikultural, Yogyakarta: Pustaka Pelajar, 2006.

Maslikhah, Quo Vadis Pendidikan Multikultur, Surabaya: STAIN Salatatiga Press dan JP Books, 2007.

Muhaimin dan Abd. Mujib, Pemikiran Pendidikan Islam. Bandung: Trigenda Karya, 1993. 
Parekh, Bhikhu, terj. C.B. Bambang Kukuh Adi, Rethinking Multikultirism: Keberagaman Budaya dan Teori Politik, Cet. Ke-5 Yogyakarta: Kanisius, 2008.

Purwanto, Ngalim. M, Administrasi dan Supervisi Pendidikan, Bandung:PT. Remaja Rosdakarya, 2010.

Rahman, Fazlur, Islam and Modernity, Transformation of an IntellectualTradition, Chicago: The University of Chicago Press, 1982.

Shihab, M. Quraish, Tafsir al-Mishbah: Pesan, Kesan, dan Keserasian al- Quran, Volume 1, Jakarta: Lentera, 2000.

Dia Dimana-mana: “Tangan” Tuhan Dibalik Setiap Fenomena, Jakarta: Lentera Hati, 2007.

M. Quraish, Tafsir al-Amanah. Jakarta: Pustaka Kartini, 1992. , Membumikan al-Qur'an. Bandung: Mizan, 1994. , Mujizat al-Qur'an. Bandung: Mizan, 1997.

"Membangun Integrasi Ilmu dan Agama: Pengalaman UIN Malang" dalam Zainal Abidin Bagir dkk. [Ed.], Integrasi Ilmu dan Agama: Interpretasi dan Aksi, Bandung: Mizan, 2005.

Sutarno, Pendidikan Multikultural. Jakarta: Ditjen Dikti, 2007.

Suriasumantri, Jujun S., Filsafat Ilmu: Sebuah Pengantar, Jakarta: Sinar Harapan, 1984.

Suyudi, Muhammad, Pendidikan Perspektif al-Qur'an. Yogyakarta: Mikraj, 2005.

Sumartana, dkk., Pluralisme, Konflik, dan Pendidikan Agama di Indonesia, Yogyakarta: Interfidei dan Pustaka Pelajar, 2001.

Suryana, Yaya dan H. A.Rusdiana, Pendidikan Multikultural (Suatu Upaya Penguatan Jati Diri Bangsa) Bandung: Pustaka Setia, 2015.

Stavenhagen, Rudolfo., Education for Multikultural World dalam Jasque Delors (et.all.). Learning: the Treasure Within. Paris: UNESCO, 1996.

Sleeter, C.E., Making Choice for Multikultural Education: Five Appoaches to Race, Class and Gender. New York: John Wiley \& Sons, 1999.

L.Tiedt, Pamela dan Iris M. Tiedt, Multicultural TeaclJing: A Handbook of Activities Information and Research, USA: Pearson Education Inc, 2005

Wahid, Abdurrahman, Islamku Islam Anda Islam Kita, Jakarta: The Wahid Institute, 2006

Yunus, Mahmud, Sejarah Pendidikan Islam. Jakarta: Hidarya Agung, 1981.

Yaqin, Ainul, Pendidikan Multikultural (Cross Cultural Understanding Untuk Demokrasi dan Keadilan, Yogyakarta:Kanisius, 2000.

Zaenudin dkk, Seluk Beluk Pendidikan dari al-Ghazali. Jakarta: Bumi Aksara, 1992. 
Zamroni, The Implementation of Multikultural Education. A Reader. Yogyakarta: Graduate Program The State University of Yogyakarta, 2010.

A Conception Frame-Work of Multikultural Teschers Education. A reader. Yogyakarta: Graduate Program The State University of Yogjakarta, 2010.

Pendidikan Demokrasi pada Masyarakat Multikultural. Yogyakarta: Gavin Kalam Utama, 2011

Zuhri, Saefudin dan Abd. Muid N., Wajah Damai Islam, cet. ke-1. Tangerang Selatan: Yayasan Nusa Institute Indonesia, 2016

Zubaedi, Pendidikan Berbasis Masyarakat, Yogyakarta: Pustaka Pelajar, 2005 